\title{
Religious values informing halal meat production and the control and delivery of halal credence quality
}

\author{
Karijn Bonne ${ }^{1}$ and Wim Verbeke ${ }^{2}$ \\ ${ }^{1}$ Department of Business Studies and Public Administration, Hogeschool Ghent, Ghent, Belgium; ${ }^{2}$ Department of Agricultural \\ Economics, Ghent University, Ghent, Belgium
}

Accepted in revised form March 24, 2007

\begin{abstract}
This paper investigates the socio-technical construction, quality control, and coordination of the credence quality attribute "halal" throughout the halal meat chain. The paper is framed within Actor-Network Theory and economic Conventions Theory. Islamic dietary laws or prescriptions, and how these are translated into production and processing standards using a HACCP-like approach, are discussed. Current halal quality coordination is strongly based on civic and domestic logics in which Muslim consumers prefer transacting with Muslim butchers, that is, individuals of known reputation with similar moral and religious obligations. The HACCP-like approach with identification of critical halal control points, as presented in this paper, fits with the industrial quality convention mechanism and ideally yields guaranteed and trustworthy halal credence quality, eventually marked by a halal meat label. The socio-technical construction of halal credence quality, for example with respect to ritual slaughter, and the quality coordination mechanism aimed at reducing halal quality uncertainty among Muslim consumers, for example through labeling, are identified as key attention points in the future research agenda.
\end{abstract}

Key words: Actor-Network theory, Conventions theory, Halal, Islam, Meat, Quality control, Religion, Supply chain

Karijn Bonne is assistant professor of marketing at Hogeschool Ghent in Belgium, Department of Business Studies and Public Administration. She obtained a Master in Business Studies with specialization in marketing management in 2000. Currently, she is enrolled as a doctoral researcher in the Department of Agricultural Economics at Ghent University in Belgium, where she is pursuing a PhD dealing with Muslim consumer attitudes and behaviors towards meat consumption.

Wim Verbeke is professor in agro-food marketing and consumer behavior, affiliated with the Department of Agricultural Economics at Ghent University in Belgium. He holds an MSc in Bio-Science Engineering, an MBA in Marketing Management, and PhD in Applied Biological Sciences. His research concerns food consumer science, with a focus on factors influencing consumer decision-making, food choice, and consumer acceptance of food production technologies and novel food products.

\section{Introduction}

Religion as an aspect of culture influences consumer attitude and behavior in general (Delener, 1994; Pettinger et al., 2004), and food purchasing decisions and eating habits in particular (Mennell et al., 1992; Steenkamp, 1993; Steptoe and Pollard, 1995; Shatenstein and Ghadirian, 1998; Asp, 1999; Mullen et al., 2000; Blackwell et al., 2001). In many societies, religion plays one of the most influential roles in food choice (Musaiger, 1993; Dindyal, 2003). The impact of religion on food consumption depends on the religion itself and on the extent to which individuals follow the teachings of their religion. Most religions forbid certain foods (e.g., pork and not ritually slaughtered meat in Judaism and Islam, pork and beef in Hinduism and Buddhism), with the notable exception of Christianity, which has no food taboos (Sack, 2001: 218). Although religions may impose strict dietary laws, the numbers of people following them may vary considerably. For instance, it has been estimated that $90 \%$ of Buddhist and Hindus (Dindyal, 2003), 75\% of Muslims, and $16 \%$ of Jews in the US follow their religious dietary laws (Hussaini, 1993a).

Islam is the fastest growing religion on earth. The total number of Muslims worldwide is estimated at 1.4 billion. Approximately 11 million Muslims live in North America and their population is growing three times faster than any other minority group (Islamic Food and Nutrition 
Council of America, 2004). Western Europe has a Muslim population of approximately 12 to 13 million Muslims who originate from North Africa and other Arabic-speaking countries, Turkey, the Indian subcontinent, Africa, and the Balkan region. Some European cities have a Muslim population of $10 \%$ or more, such as Brussels with 17\% (De Ley, 2004). In Belgium, there are approximately 400,000 Muslims, originating mainly from North Africa and Turkey, who make up $4 \%$ of the Belgian population (Bousetta and Maréchal, 2004). As such, the Muslim population constitutes a considerable market segment in today's food market.

Islam is a way of life governed by rules and customs built on five pillars, which every Muslim has to observe: shahadah or witnessing; salat or prayer; zakah or charity; sawm or fasting; and hajj or pilgrimage. In addition to these, Muslims have to follow a set of dietary laws intended to advance their well-being.

Although the halal market in North America and the United Kingdom have been the subject of some studies, research on European Muslims' food choice in general and meat consumption in particular is extremely rare. Results of a household panel survey in the Netherlands (Foquz, 1998) showed that Muslim immigrants are heavy meat consumers. The average meat consumption per Dutch consumer was $35.6 \mathrm{~kg}$ in 1998. Turkish consumers, however, ate on average $61.3 \mathrm{~kg}$ meat per year and Moroccan consumers $57.1 \mathrm{~kg}$ per year. The total spending power of Muslims in the US was estimated at $\$ 12$ billion in 1999, of which $\$ 3$ billion went for meat and poultry (Riaz, 1999). The global halal market for foods is estimated at 1.5 billion consumers (Riaz and Chaudry, 2004: 31), which means that one in four consumers worldwide buys halal products. ${ }^{1}$ Until recently, the food industry has largely ignored this Muslim consumer segment. In contrast with the well-developed kosher market (on average $30 \%$ to $40 \%$ of the grocery items in US supermarkets are kosher) (Hunter, 1997), halal food products on the shelves of the supermarkets are rather scarce. In the past, Muslim minorities simply avoided foods that did not meet their dietary standards or bought kosher foods when available. Nowadays, Muslims are making their presence felt socially and politically and are requesting halal-labeled food products. In France, for example, the first fast food restaurant, Beurger King Muslim, opened in 2005 targeting young Muslims desiring halal convenience foods. ${ }^{2}$ It differentiates itself from other ethnic, halal restaurants by publicly confirming its Islamic identity and thereby it responds to the rise of a strong Islamic attitude among young Muslims expressed by consuming halal foods and wearing Islamic inspired clothing (Bergeaud-Blackler, 2006).

Muslims in Europe are mainly immigrants; hence, the question arises whether they maintain their food habits or adapts their food choice to their new food and cultural environment. The complex process by which immigrants adopt the eating patterns or food choices of the host country is referred to as dietary acculturation. Acculturation denotes the process by which a racial or ethnic group, usually a minority, adopts the cultural patterns such as beliefs, religion, diets, and language of the host culture (Jamal, 1996; Laroche et al., 1999). Cultural factors may directly influence dietary acculturation independent of exposure to the host culture or changes in psychosocial and environmental factors (Satia-Abouta et al., 2002; Verbeke and Poquiviqui López, 2005). Nevertheless, immigrants' food habits may change more slowly than other more visible aspects of culture such as language or clothing because many meals are eaten in the privacy of one's home and food habits are unique and fundamental to most cultures (Park et al., 2003). Levenstein (1985) argues that immigrants and ethnic minorities try to maintain their own cooking and eating habits as long as possible, even against strong pressure to change them. However, some foods or ingredients may not be available in the new environment. Faragallah et al. (1997) suggest that many Arabs (especially Muslim Arabs) in the US find acculturation to be more difficult than other immigrants. In contrast, the Jewish dietary laws were the first to be abandoned by Jewish immigrants in urban neighborhoods of North America as communal pressure faded away and even for those wanting to observe them, limited availability of kosher foods rendered kosher food consumption very difficult (Diamond, 2000).

Halal is a credence quality attribute, i.e., a product characteristic that cannot be evaluated or ascertained by the individual consumer, even upon or after consuming the good (Darby and Karni, 1973; Grunert, 2005). As a product attribute, "halal" refers to the nature, origin, and the processing method of the food product, which entails similarities with organic foods and foods produced taking animal welfare or sustainability issues into account. In either case, the presence of the credence quality has to be clearly communicated e.g., through an indication on-pack or on-label. Furthermore, in order to have some utility value to the consumer and to be useful for purchasing decision-making, the communication source and message conveyed with respect to the credence quality have to be trustworthy and believable (Verbeke, 2005).

A relevant issue pertains to the values (religious prescriptions in this particular case) informing halal meat production, and to how halal as a credence quality becomes socially and technically constructed in today's meat supply chain. In line with this, the objective of this paper is to explore the socio-technical construction and quality coordination of halal meat, following principles from Actor-Network Theory (ANT) and economic Conventions Theory (CT). The aim is to demonstrate 
how halal standards can be met in production and processing and how halal quality uncertainty can be reduced during delivery and retailing. Since ANT and CT have recently been reviewed quite extensively and applied in an agro-food context by Vannoppen et al. (2004), Straete (2004), and Kirwan (2006), among others, only the basic and relevant principles of both theories will be introduced in the following section.

\section{Conceptual framework}

Halal is a typical example of what Kirwan (2006) refers to as a socially constructed quality criterion, which incorporates not only the physical properties of the product but also the conditions under which it is produced, distributed, and retailed. Actor-Network Theory (ANT) (Callon, 1991) is a way of analyzing how actors in a network negotiate whether and how certain product attributes and their production method will be included in the product specification. It allows examining the processes of industrial transformation, which occur at every stage of the network or food chain, and investigating how the various components interlock to strongly configure the behaviors of the actors involved (Murdoch, 2000). Actors involved in networks or supply chains, which act as socio-technical regimes that incorporate a specific claim of quality (Wiskerke, 2003), develop and define a product's specific quality and spell it out in the product specification. The decisions depend on the different motivations of the actors, economic necessities, technical constraints, and cultural choices (De Roest and Dufour, 2000). In the specific case of the halal meat chain, the socio-technical construction of halal is informed by dietary laws, values or religious prescriptions, which act as a means of definition for the desired quality. This sociotechnical construction is laid down in a set of principles, standards, and rules to be applied and monitored throughout the production process and the supply chain, such as proposed by Riaz and Chaudry (2004) for the specific case of halal meat using HACCP as an assurance system for halal quality.

Respecting above-mentioned standards, with a label signaling halal quality as a potential outcome, is typified as industrial coordination within the economic Conventions Theory (CT) (Eymard-Duvernay, 1989). Similar to ANT, the CT focuses on quality, in particular on the social and cognitive construction of quality, hence, also offering an appropriate theoretical framework for the examination of socially constructed food quality criteria (Kirwan, 2006). Conventions are defined as a set of mechanisms and rules involving the content of product specifications, roles of third parties, strategies of product differentiation and labeling (Sauvée, 1998), and are used for defining and recognizing the quality of products and for solving problems related to quality uncertainty (Vannoppen et al., 2004). Building on the seminal work by Boltanski and Thévenot (1991), Salais and Storper (1992), and Storper (1997), four models of production (also, types of quality conventions and coordination mechanisms), with particular applicability to food and the agro-food system, were identified (Sauvée, 1998): industrial, market, civic, and domestic coordination. As mentioned before, industrial coordination is based on respecting standards; the resulting compliance with standards signals quality. In market coordination, supply-demand relations and price act as quality signals. Civic coordination is based on a set of collective principles to which actors adhere. Domestic coordination is based on face-to-face relationships and on personal trust that has been established over previous transactions. ${ }^{3}$ Because of the intangible and credence nature of "halal," domestic and civic conventions are likely to dominate depending on the degree of quality uncertainty. The specification and monitoring of industry standards and norms, eventually followed by the establishment of a halal quality label, may shift the legitimation of halal quality to a more industrial coordination mechanism.

The resulting conceptual framework for our qualitative analysis of the socio-technical construction and quality coordination of halal meat using HACCP as a potential quality assurance system is presented in Figure 1. The framework illustrates how a HACCP approach can derive from ANT and CT principles with the aim to producing and marketing desired credence qualities. Specifically, Islamic religious values and dietary laws form the basis for negotiating about the socio-technical construction and quality coordination of halal meat quality, and feed the consensus on specific standards and rules for halal meat production and control. The implementation of an integrated quality assurance system following HACCPprinciples with identification and monitoring of critical control points at different levels of the meat chain could be a vehicle for guaranteeing halal meat quality and reducing halal quality uncertainty for the Muslim con-

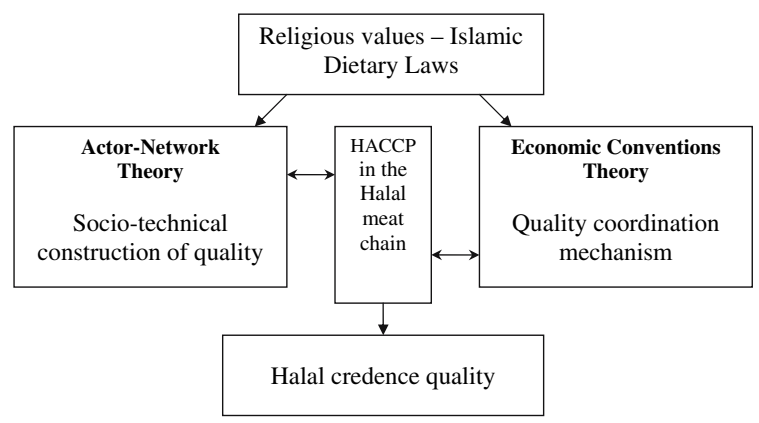

Figure 1. Conceptual framework for analyzing the sociotechnical construction and quality coordination mechanism for halal credence quality. 
sumer. It should be noted that the ANT and CT theories are introduced with the primary aim of providing a unifying theoretical framework for the descriptive analysis in this paper.

In the following sections, Islamic dietary laws or religious prescriptions and their translation into meat production, processing, and retailing standards are set forth proposing HACCP as a potential quality assurance tool for monitoring, controlling, and guaranteeing the halal status of meat.

\section{Islamic dietary laws}

The basic guidance about the food laws for Muslims is revealed in the Quran (the divine book) and is explained and put into practice through the Sunnah (the life, actions, and teachings of Prophet Muhammad) as recorded in the Hadith (the compilation of the traditions of Prophet Muhammad). In reference to Islam, halal is an Arabic word meaning lawful or permitted or that what is permitted and allowed by the lawgiver (Allah) and haram means unlawful or prohibited. Makrooh means discouraged or detested or what is disapproved by Allah. However, makrooh is not strongly detested, only in a less degree than halal. Finally, mashbooh means suspected; it is used to indicate the grey area between halal and haram and is best avoided.

General Quranic guidance dictates that all foods are halal except for those that are specifically mentioned as haram in the Quran or in an authentic Hadith:

$\mathrm{O}$ ye who believe! Eat of the good things wherewith We have provided you, and render thanks to Allah, of it is $\mathrm{He}$ whom ye worship (The Quran, chapter 2, verse 168).

Human beings cannot forbid the halal and permit the haram:

And, for what your tongues describe, do not utter the lie, (saying) this is lawful and this is unlawful, in order to forge a lie against Allah; surely those who forge the lie against Allah shall not prosper (The Quran, chapter 16 , verse 116).

Islamic dietary laws prohibit the consumption of alcohol, pork, blood, dead meat, and meat which has not been slaughtered according to Islamic rulings. These laws are binding and must be observed at all times. Meat is the most strictly regulated of all foods in Islam. Shatenstein and Ghadirian (1998: 226) remark that "many of the foods prohibited by religions on a temporary or permanent basis are of animal origin." The haram foods may include halal food items, which have been mixed or contaminated with haram food (Riaz and Chaudry, 2004: 11). They are specifically mentioned in the following four verses of the Quran:
- He hath forbidden you only carrion, and blood, and swine flesh, and that which hath been immolated to any other than Allah ... (The Quran, chapter 2, verse 173).

- Forbidden unto you (for food) are: carrion and blood and swine flesh, and that which hath been dedicated unto any other than Allah, and the strangled, and the dead through beating, and the dead through falling from a height, and that hath been killed by the goring of horns, and the devoured of wild beasts saving that which ye make lawful and that which hath been immolated to idols. And that ye swear by the divining arrows. This is an abomination.... (The Quran, chapter 5 , verse 3 ).

- Say: I do not find in that which has been revealed to me anything forbidden for an eater to eat of except that it be what has died of itself, or blood poured forth, or flesh of swine - for that surely is unclean - or that which is a transgression, other than (the name of) Allah having been invoked on it; but whoever is driven to necessity, not desiring nor exceeding the limit, then surely your Lord is Forgiving, Merciful (The Quran, chapter 6, verse 145).

- He has only forbidden you what dies of itself and blood and flesh of swine and that over which any other name than that of Allah has been invoked, but whoever is driven to necessity, not desiring nor exceeding the limit, then surely Allah is Forgiving, Merciful (The Quran, chapter 16, verse 115).

Following these four Quranic verses, it is widely acknowledged that the Quran only prohibits four animal products: blood, swine, carrion or dead meat, and meat that has been immolated to idols. In the Quran there are no other prohibitions on foods, but Islamic jurists have widened the list of prohibited foods and permitted foods by interpreting other Quranic verses and hadiths. As a result, also prohibited are: carnivorous animals with fangs, e.g., lions, dogs, wolves, and tigers; birds with sharp claws (birds of prey), e.g., falcons, eagles, owls, and vultures; land animals without ears, e.g., frogs and snakes; and the rat. Animals that are permitted are: ovine and bovine animals; poultry; camels; horses; wild donkeys; rabbits; hedgehogs; porcupines; grasshoppers; worms in fruits; birds; animals that live in the sea with exemption of frogs, eels, crocodiles, sea turtles, dolphins, and sharks.

As mentioned before, meat is the most strictly regulated of the food groups (Chaudry, 1992). Apart from some prohibited animal products, the legal purification of the animal or bird for human consumption through ritual slaughter, is regulated in the Islamic law or Shari'ah. Fish and other creatures that live in the water need not be ritually slaughtered. The meat of animals slaughtered according to the conditions is called zabiha or dhabiha meat, meaning purified or rendered good or wholesome. More insights in the slaughter and retail conditions for halal meat will be discussed further in this paper. 
Although some Muslims consider food of the people of the book (Jews or Christians) as lawful, the majority of the Islamic scholars share the opinion that their food must also meet the halal criteria, including the proper slaughter of animals. Chaudry et al. (2000) state that when halal meat slaughtered by Muslims is available, there is no need or reason to accept meat slaughtered by Jews or Christians. In practice, approximately $75 \%$ of the Muslims in North America follow the Islamic dietary rules, especially the avoidance of pork meat (Hunter, 1997). Consumption of pork by a Muslim would mean rejection of faith and group rulings and could be interpreted as a voluntary willingness to leave the subculture. Nevertheless, alcohol consumption, which is also punishable according to the Quran, is more or less tolerated since its consumption provides a certain pleasure in contrast to the consumption of pork meat (Benkheira, 1997; 1999).

Benkheira (1995) provides several reasons for refusing regular meat by Muslims in Europe. The first reason is the use of stunning methods in European countries for nonritual slaughter that might kill the animal before slaughter and thus render this meat prohibited. Second, the possible contact between halal and haram meat (for example pork) which would turn the halal meat into haram. Furthermore, Muslims who live in countries where they form minorities, tend to return to rites of social life in quest for identity. They find ritual prohibitions (marital, sexual, and dietary in particular) very important. Finally, Benkheira (1995) perceives a very strong aversion for pork meat and not ritual slaughtered meat among Muslims in Europe. According to Gezairy (World Health Organization, 1997), many Muslims abstain from eating meat when living or traveling in non-Muslim countries where facilities for Islamic slaughter are not available.

In the past, Muslims in the US accepted kosher foods since they believed the slaughter was similar to halal slaughter and at least the animal received blessings during slaughter. However, Muslims are now learning that kosher and halal do not meet the same standards. Although both religions determine which foods are fit or proper for human consumption and determine ritual slaughter methods, there are major differences between the Islamic and the Jewish dietary laws which render also kosher certified meat not a feasible alternative for Muslims strictly following Islamic dietary laws. ${ }^{4}$ Young Muslims in France, for example, even consider permitted foods, such as kosher, as unlawful (Bergeaud-Blackler, 2006).

\section{The halal meat chain}

\section{Principle of quality assurance}

The meat chain meeting all prescribed religious criteria is very complex and, besides controversy on some issues, there is a risk for cross-contamination at all stages, as halal meat becomes haram for example when in contact with pork meat. In addition, halal meat safety and wholesomeness in terms of the halal status is difficult to verify by consumers before purchase, during consumption, and even after, resulting in potentially uncertain quality. In this situation, implementation of a quality assurance scheme is a prerequisite so that stakeholders involved in the meat chain can claim and trust that halal meat fulfils the defined quality requirements.

Hazard Analysis Critical Control Points (HACCP) (Codex Alimentarius Commission, 2003) is a worldwide recognized and applied quality assurance system within companies situated at different levels of the agro-food chain. It consists of seven principles constituting a stepwise approach to identify potential hazards and critical control points (CCPs) where operational failures might create or fail to eliminate eventual hazards. It has become the internationally recognized standard for achieving the highest possible levels of food safety throughout the food chain (EurLex 93/43/EEG). The focus of quality assurance schemes has changed over time from management tools to assure food safety into more comprehensive approaches allowing the assurance and safeguarding of process standards, relating for example to animal welfare and certified production methods such as organic or halal (Wood et al., 1998; Fearne et al., 2001; Juska et al., 2003; Ten Eyck et al., 2006). Issues of debate pertain to the identification of critical control points, for which a scientific basis sometimes is lacking (Bolton et al., 2001); to costs and benefits incurred by its establishment and implementation; and to the fact that it is basically a management tool for self-regulation, requiring assessment and auditing by a third party with independent inspectors.

Growing demand for ritually slaughtered meat and the need for good practices from an animal welfare perspective were recently raised by Cenci-Goga et al. (2004), who concluded that proper handling requires continuous measurement, monitoring and management. Riaz and Chaudry (2004) have first introduced a HACCP approach with several halal critical control points at the slaughterhouse level to ensure the halal status of meat. However, a total or integrated halal quality approach would require that the entire halal meat chain is controlled in accordance with HACCP principles. In this respect, Zadernowski et al. (2001) and Snijders and van Knapen (2002) stressed that intervention should not focus at the abattoir or food processing stages only; it should also target risks associated with upstream preharvest production and downstream retailing in the farm to fork chain. According to these authors, properly structured HACCP-like methods applied from the farm to the kitchen offer the best available approach to optimize meat inspection. This viewpoint has been adopted by 
Wyss and Brandt (2005) for organic foods resulting in the organic HACCP concept. This organic HACCP differs from standard HACCP in three aspects: it covers the entire chain, not just one enterprise; it is concerned with safeguarding a range of qualities, including taste, trustworthiness, and authenticity, not just safety in the sense of preventing a potential health hazard; and it concentrates on the aspects of procedures for the analysis of risks. Within this concept, critical control points are defined as steps at which controls should be performed to prevent or eliminate a risk rather than a food safety hazard. A similar approach, specifically applied to the halal meat chain and adapted from Riaz and Chaudry (2004), is presented in Figure 2. The Islamic dietary prescriptions, and their translation into a socio-technical regime for producing halal quality, form the basis for defining the halal critical control points (HCPs). This process is set forth in the following sections.

\section{Halal breeding - HCP1}

The animal must be of an acceptable species. Prohibited species such as pork cannot be turned into halal through halal slaughter. Although most authors stress the slaughter conditions in Islam, the breeding of animals

Halal Meat Supply Chain Halal Control Points

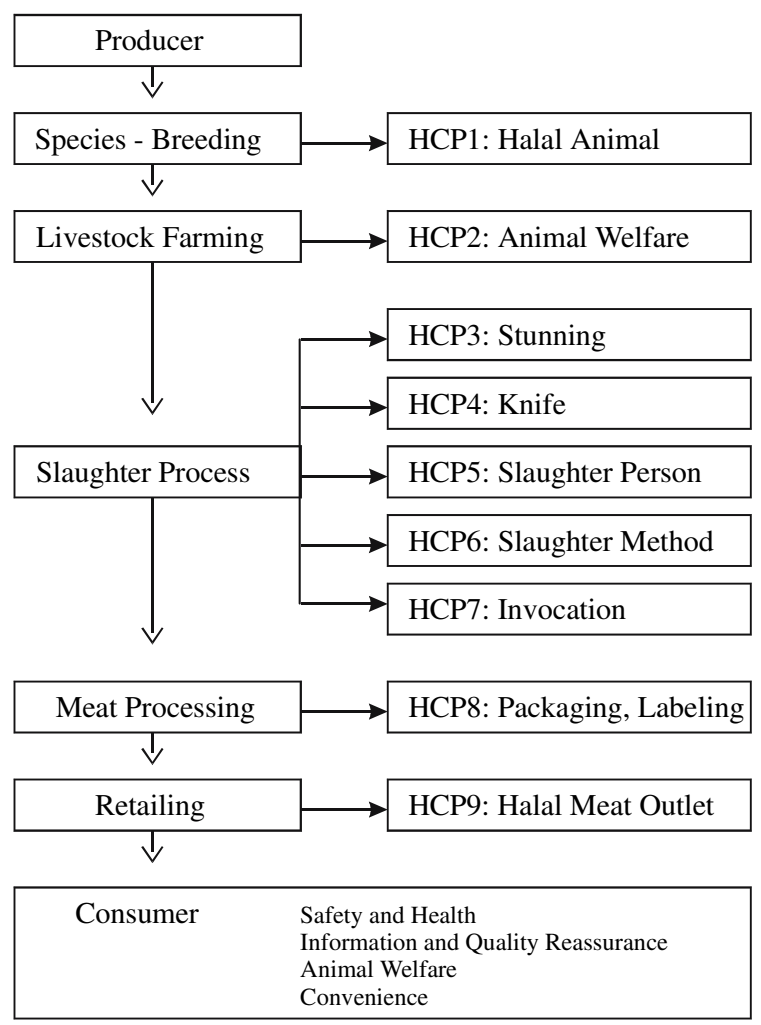

Figure 2. The halal meat chain and identification of Halal Control Points (HCP) Based on: Riaz and Chaudry (2004). should be halal as well. In the Hadith, according to AbuDawud, it is recorded:

The Apostle of Allah prohibited eating the animal, which feeds on filth and drinking its milk (Book 27, 3776).

Religious scholars agree that it is forbidden for Muslims to consume animals that have eaten filth, which is considered as an unnatural, non-vegetarian diet. If this animal is nearly starved to death during three till 40 days and than fed a natural, vegetarian diet, the animal becomes fit for consumption. Consequently, animals that are fed meat of other animals or animal protein are forbidden. In addition, when cross-contamination between acceptable and prohibited meat occurs, the acceptable meat becomes prohibited. Therefore, halal and haram meat should be separated at all stages of the halal meat chain. Genetically modified (GM) foods could be a cause of cross-contamination as well. It is not clear yet whether these foods are allowed or forbidden for Muslims. God requires Muslims to eat of the good things:

Eat of the good things wherewith We have provided you, and transgress not in respect thereof lest My wrath come upon you; and he on whom My wrath cometh, he is lost indeed (The Quran, chapter 20, verse 81).

All forbidden foods are prescribed in the Quran or in the Hadith. Since biotechnology did not exist in ancient times, only religious scholars can tell whether GM foods are either haram or halal. However, until now, they have not edited any religious ruling that would permit or prohibit these foods (Regenstein et al., 2003b), leaving individuals free to interpret the Quran and Hadith on biotechnology. The most plausible interpretation is that GM foods containing only derivatives from halal foods are halal and GM foods containing derivatives from haram foods are haram. This interpretation is supported by the Islamic Food and Nutrition Council of America and the Islamic Jurisprudence Council in the US. It is, however, not always clear whether a GM food contains a halal or haram derivative and therefore GM foods could be interpreted as being mashbooh meaning doubtful and thus to be avoided. Most of the religious people interviewed by Maarabouni (2002) support this view. In addition to these two possible interpretations, Maarabouni (2002) adds that Muslims must take care of nature and let nothing harm the environment since earth and nature are given to them by God. If GM foods would have a negative impact on nature, than they would be bad for mankind and therefore forbidden. Moses (1999) agrees that consumer objections to GM products may stem from concerns about possible hazards as well as ethical considerations. Based on faith and belief, people may regard biotechnology as an affront to nature, something that is beyond the right of man and should be left to God. 
Animal welfare - $\mathrm{HCP} 2$

A second point of control in the halal meat chain pertains to animal welfare. Islam advocates humane treatment of animals before, during and after slaughter. Animals should be treated as such that they are not stressed or excited prior to slaughter; they should be nourished and well rested and drinking water must be available in holding areas. In addition, the knife should not be sharpened in front of the animal and no animal should be able to witness the slaughter of another animal. Several verses in the Hadith support this viewpoint on animal welfare.

- Shaddid b. Aus said: "Two are the things which I remember Allah's Messenger (may peace be upon him) having said: Verily Allah has enjoined goodness to everything; so when you kill, kill in a good way and when you slaughter, slaughter in a good way. So every one of you should sharpen his knife, and let the slaughtered animal die comfortably." (Sahih Muslim, Book 021, Number 4810)

- Narrated Hisham bin Zaid: "Jabir b. 'Abdullah reported that Allah's Messenger (may peace be upon him) forbade that any beast should be killed after it has been tied." (Sahih Muslim, book 021, number 4817)

\section{Stunning - HCP3}

The question whether stunning is allowed before halal slaughter remains an issue of debate, both within and beyond the Muslim community. According to Riaz and Chaudry (2004), stunning is preferably not used since the animal must be alive at the time of slaying and must die of bleeding rather than as a consequence of stunning. Aldeeb (2001), however, notes that Islamic dietary laws do not prohibit stunning; they forbid consumption of blood and dead animals and encourage humane handling prior to and during slaughter. Stunning, as long as it does not kill the animal, could thus be accepted to reduce suffering and meets the religious prescriptions of humane handling. Additionally, several fatwas have been written by religious scholars who confirm Aldeeb's position towards stunning. ${ }^{5}$ A fatwa from 1987, for example, issued by the Egyptian fatwa commission states that stunning is permitted when it is used to reduce suffering during slaughter without causing the death of the animal.

In many European countries such as Belgium, the UK, France, Germany and the Netherlands, regulations on animal welfare require that all animals must be rendered insensible before being slaughtered, except for religious or ritual slaughter. Other European countries such as Denmark, Switzerland, Norway and Sweden do not grant exemptions from stunning for halal and kosher slaughter. In response to the international market development and opportunities for halal meat, New Zealand, the largest exporter of halal slaughtered sheep meat and an important exporter of halal slaughtered beef, has supported research in the late 1970s to develop slaughter and stunning techniques that would meet both Muslim requirements and animal welfare concerns. The result was a head-only electrical stun that renders the animal only temporarily unconscious. If the animal were not slaughtered, it would thus regain conscious. Most Muslims, however, are opposed to stunning since they believe it is strictly prohibited by Islamic rulings.

\section{Knife - HCP4}

A fourth halal control point is the knife used for slaughter. This must be so sharp that the animal does not feel the pain of the cut especially when no stunning is used. The size of the knife should be proportioned to the size of the neck. As indicated before, the knife should not be sharpened in front of the animal for animal welfare reasons.

\section{Slaughter person - HCP5}

The slaughter person must be a sane, adult Muslim male or female or someone from "the people of the book," namely a Jew or a Christian. Two schools of thought of Islamic jurisprudence claim that although Jews and Christians are considered to be people of the book, the meat which is slaughtered by them is prohibited unless the name of God is mentioned while slaughtering. ${ }^{6}$ Another school of thought considers the meat slaughtered by Jews or Christians halal without restriction since it is allowed by the Quran and they claim that the prophet Muhammad used to eat meat prepared by Jews or Christians (Sakr, 1971, Hussaini, 1993b). The Muslim must invoke the name of God before eating this meat since his name was not invoked during slaughter:

This day are (all) good things made lawful for you. The food ( $\mathrm{ta}^{\prime} \mathrm{am}$ ) of those who have received the Scriptures is lawful for you, and your food is lawful for them ... (The Quran, chapter 5, verse 5).

The application of a right cut is crucial to humane handling of the animal during slaughter. This requires that Muslim slaughter men are well trained and experienced for their job. Although the competent authorities license slaughter men, monitoring of slaughter methods is mostly lacking (Sartirano et al., 2000 in Cenci-Coga et al., 2004).

\section{Slaughter method - HCP6}

The animal should be slaughtered by cutting the front part of the neck, severing the carotids, jugulars, trachea, 
and esophagus without reaching the bone in the neck. It is preferable to turn the animal or bird towards Makkah before slaughtering; however, this is only a secondary requirement.

Normally the slaughtering process of ruminants and poultry should be performed by hand. Slaughtering by hand is preferred by all Muslims and widely followed in countries where Muslims manage slaughterhouses. However, in Western countries mechanical or machine slaughter of birds is gaining acceptance among Muslims.

\section{Invocation - HCP7}

The name of Allah must be invoked while cutting. The usual formula is "In the name of Allah; Allah is the greatest" (Bismillah, Allahu' akbar). There are two main reasons to say this blessing during slaughter. The first reason is to remind the slaughterer of his responsibility in observing the prescribed requirements and to remove any doubt as to whom the animals are dedicated (Abdussalam, 1981). Second, it reinforces the notion that the animal is being slaughtered in the name of Allah for food and not for recreational purposes:

- And do not eat of that on which Allah's name has not been mentioned, and that is most surely a transgression; and most surely the Shaitans suggest to their friends that they should contend with you; and if you obey them, you shall most surely be polytheists (The Quran, chapter 6, verse 121).

- Therefore eat of that on which Allah's name has been mentioned if you are believers in His communications (The Quran, chapter 6, verse 118).

The blessing must be pronounced when passing the knife on the neck of the animal. If the slaughterer is someone from "the people of the book," he should not invoke another name than God. If he invokes the name of Jesus or Abraham, the meat is haram. All schools of thought agree that if the name of another person instead of God is mentioned, the meat is entirely prohibited (Sakr, 1971). Benkheira (2002: 77), however, mentions that invocation is only a secondary condition and that if the slaughter men should forget, the meat does not become haram.

In the case of mechanical Islamic slaughter, the following actions should be performed. A Muslim switches on the machine while pronouncing the name of God. One Muslim slaughter person is positioned behind the machine to make a cut on the neck if the machine misses a bird or if the cut is not adequate for proper bleeding. This person invokes continuously the name of God during slaughter. Neither saying a blessing only at the beginning of the process nor the use of recordings of blessings is allowed.

\section{Packaging and labeling - HCP8}

For meat to be labeled properly as halal, all the halal control points in the halal meat chain should be evaluated by a reputable supervisory organization, which acts as a third and independent control certification body. Each slaughter should be halal certified individually, unless the slaughterhouse is exclusively a halal-slaughtering facility.

\section{Retailing - HCP9}

Although most authors only stress evaluation of the slaughter process itself, distribution and retailing of halal meat is a critical issue as well in order to prevent crosscontamination. In practice, three distribution channels are available for halal meat: the Islamic butcher, the supermarket, and the farm or slaughterhouse. The first and most important distribution channel is the Islamic butcher shop, mainly owned by immigrants. It is estimated that $80 \%$ of the halal meat is purchased at the Islamic butcher in France (Haut Conseil à l'Intégration, 2000 ) and $75 \%$ in the Netherlands (Foquz, 1998). Exploratory research with Moroccan families in Belgium showed that $94 \%$ of the families always buy meat from an Islamic butcher. Secondly, $10 \%$ of the halal meat in France is bought at the supermarket. In the Netherlands and Belgium, this channel accounts for only 3 to $4 \%$ of the halal meat market. Belgian supermarkets do not offer fresh halal meat for sale; some sell frozen halal processed meats. Finally, some Muslims go directly to the slaughterhouse to buy their halal meat or buy animals from the farmer to slaughter themselves at home (which is an illegal practice in most European countries) or at the farm. In the Netherlands, 10 to $13 \%$ of the halal meat is bought directly from the farmer and slaughtered on the farm or at home. In France, this distribution channel is estimated to account for $10 \%$ of the halal meat market. About $68 \%$ of the Moroccan families in Ghent claimed to buy sometimes an animal at the farm. However, almost every Muslim family buys once a year a sheep for Eid-elAdha at a farm.

\section{Discussion}

Muslims constitute an important and growing market segment for foods. In Muslim countries and even more in countries with Muslim minorities, Muslims are attentive to the content of their foods especially since food chains are becoming longer and more complex (BergeaudBlackler, 2005), which may fuel uncertainty relating to process characteristics and credence attributes unless these are clearly and in a trustworthy way signaled to the end consumer. Furthermore, the conception of halal has 
become symbolic and emotional on top of religious (Bergeaud-Blackler, 2006), in particular among second and third generation Muslims in immigrant populations. Last but not least, not only cultural or religious motives shape halal consumption, but also to a growing extent health, convenience, social and ethical issues such as ethnic identity and respect for animal welfare (Bonne and Verbeke, 2006). The evolution of the definition and symbolic meaning of halal, together with emerging shopping and eating habits among young generations entail particular challenges for producing, controlling, and guaranteeing the credence quality that is "halal." This paper has explored ways in which a HACCP-like approach, with the identification and monitoring of halal critical control points, can meet halal standards as informed by Islamic dietary laws and reduce quality uncertainty at the consumer level.

\section{The socio-technical construction of halal quality}

It is clear that in order to meet Muslim consumers' demand for halal meat in European countries, Islamic dietary laws should form the basis for the socio-technical construction of halal, resulting in a set of principles, standards, and rules to be applied throughout the production and distribution process. However, not all of these principles are observed in many of today's halal meat chains in Europe. In Belgium, for example, most principles have yet to be formalized and are thus not controlled.

For a quality assurance scheme such as HACCP to be efficient and successful, all potential hazards in the chain should be identified and scientific information for systematic assessments should be provided (Lund, 2002). The complex halal meat chain consists of actors such as breeders, slaughterhouses, certifying agencies, retailers, consumers, and religious representatives, who often have different stakes in and viewpoints on halal meat production and processing. Following the ANT, the motivations of the different actors within the meat chain, technical constraints, economic necessities or cultural choices are crucial in this discussion (De Roest and Dufour, 2000).

One fundamental problem that arises in the halal chain is reaching an agreement on the definition of halal meat and its socio-technical construction throughout the chain. Technical constraints and issues of debate relate mainly to appropriate stunning methods - if any are to be used and to the possible use of specific restrainer systems for cattle during the ritual slaughter process not involving stunning. The major challenges pertain to providing a sound scientific basis for the debate, and for network actors to identify and agree on potential hazards and negotiate about the translation of dietary laws into concrete product specifications and process characteristics, including a set of standards and critical limits of the identified control points throughout the halal meat chain. These challenges are soon expected to become important food policy issues in European countries (BergeaudBlackler, 2004), and hence deserve particular attention on future research agendas.

\section{Certification and quality reassurance}

Another and strongly related critical issue is who should monitor, control, and certify halal quality, i.e., the issue of third party responsibility and authority for quality assessment and auditing. In most European countries, institutionalized quality reassurance systems are lacking and very few private and independent certification organizations are active. Hence, today's trust in halal meat is mainly based on personal confidence, much more than on institutional confidence. In Belgium, for example, the Islam religion has been legally recognized in 1974. However, for many years no central ruling authority was established for Islam. This changed in 1998 with the establishment of the Belgian Muslim Executive (EMB) as a representative institution for resident Muslims. EMB has been charged with the introduction and execution of halal certification in Belgium. It remains unclear though whether all Islamic requirements, from breeding to retailing, are inspected and included in the certification process. Since several principles of halal meat have not been formalized yet, they are obviously not controlled. EMB claims to be working on the supervision of the halal chain; however, by the beginning of 2007, still no controlled and certified halal label has been introduced in Belgium. In practice, EMB only certifies that the slaughterer is a Muslim. Whether halal meat is the product of halal breeding practices, whether animal welfare is respected before and during slaughter, whether the right slaughter method is used or whether no cross-contamination has occurred is not clear, and definitely not certified at this point in time.

\section{Domestic and civic logics in the halal quality convention}

The current halal quality convention builds mainly on civic and domestic logics (described earlier in the paper). Buying at the Islamic butcher is exemplary for behavior where product authenticity and trust are mediated through personal interaction. This viewpoint, also called relational trust by Kjaernes and Dulsrud (1998), posits that trust emerges from the interaction with the individual and is based on previous experiences with the individual. Quality uncertainty is reduced because the actors trust that their counterparts will provide and pay for the desired quality because they know each other well or because they agreed and trust that the exchanged product stands for the desired quality. 
Becker et al. (2000) also concluded that familiar butchers, with whom consumers have good personal contact, are by far the most trusted source of information about the credence characteristics of meat in general. Similar findings have been reported with respect to organic products, where lower trust in institutionalized quality control as signaled through the organic label, associated with a higher likelihood of buying organic products in specialty shops where advice and personal reassurance could be asked for (Bech-Larsen and Grunert, 2001). This type of quality convention, with a strong preference for transacting with individuals of known reputation, is typical of domestic coordination.

Trust is also strongly based on the fact that the butcher is a Muslim who is considered to be responsible for his acts toward God. In this sense, meat sold by a Muslim is always to be trusted even when information about the halal status is not directly available (Benkheira, 2002: 78). Whereas Islamic butchers are almost completely trusted, supermarkets are perceived as being unhygienic since Muslim consumers lack information on the supply chain and cannot be reassured that no cross-contamination has occurred. Therefore, a major part of the quality convention is also related to the civic logic where the coordination of quality is based on a set of collective - in this particular case, religiously inspired - principles to which the actors adhere. The halal credence quality is linked to a common good or aim that the actors share and attempt to realize and for which they are prepared to reduce their own interests (e.g., convenience in purchasing).

\section{The industrial logic and halal quality labeling}

In accordance with non-Muslims, young Muslim consumers also look for convenience in shopping and want to be guided by labeling information (Bergeaud-Blackler, 2006). Clearly, convenience during shopping is a major weakness in the halal meat chain, in particular in countries with a Muslim minority. Only recently, some European retailers like Carrefour, Auchan or Leclerc in France and Albert Heijn in the Netherlands added fresh halal meat to their assortments. For some of them, this extension of their conventional product assortment is only considered a test case. When fresh halal meat in supermarkets is not available, when it is distrusted, or when cultural barriers prevent from shopping at supermarkets (because of language problems for example), Muslims see no other option than turning to Islamic butcher shops, preferably one owned by someone from the buyer's home country. Indeed, North African Muslims rarely visit a Turkish butcher and vice versa. Nevertheless, second or third generation Muslims are breaking with the shopping habits of their parents based on an established personal relationship with the Islamic butcher, and thus also with the established domestic and civic quality coordination mechanisms. As a result, industrial coordination emerges as the alternative logic in order to reduce halal quality uncertainty.

Well-defined and externally controlled principles are an absolute prerequisite for a successful industrial logic. It is known that the industrial logic has particular weaknesses when it deals with providing credence characteristics, which is exactly the case with halal quality. The HACCP approach with halal control points follows the industrial logic, and could be the vehicle for guaranteeing halal meat quality. As indicated before, some principles are still debated and halal quality is not yet certified by an independent and trustworthy authority or label, hence quality reassurance based on the industrial logic seems not to suffice yet and consumers seek additional reassurance through domestic and civic coordination mechanisms. The lack of a scheme and authority for systematic monitoring and controlling of the halal control points throughout the meat chain, together with the lack of a trustworthy halal quality signal or label, drive consumers to seek additional reassurance through civic quality coordination. The major challenge for the implementation of a successful industrial logic lies in lifting the existing barriers relating to the definition of principles and standards and the establishment of independent control mechanisms that signal halal quality through a trustworthy label.

\section{Conclusions}

Religion influences eating habits even within a new cultural environment as is the case for Muslim migrants. In order to meet the specific religious-inspired requirements, the meat chain is to be adjusted to Islamic conditions for halal meat production and retailing in order to translate the desired process attribute into a set of principles, standards, and specifications of halal meat production. An integrated quality assurance system based on HACCP-principles with halal control points is needed, together with institutionalized monitoring, controlling, and guaranteeing of these principles, standards, and rules resulting in a halal meat status. This status can eventually be signaled to consumers by means of a label so as to reduce quality uncertainty in cases where domestic and civic quality coordination fall short.

A halal quality label based on well-defined and externally controlled principles is likely to gain momentum since consumers are increasingly keen on convenience in shopping and since retailers are expected to play an increasingly important role in contemporary food chains. Hence, a major challenge pertains to shifting the construction of halal credence quality from a domestic and civic coordination, where consumers rely on personal interaction for quality reassurance, to an industrial coordination of quality with a trustworthy label. However, 
technical constraints, diverging opinions of the involved stakeholders, lack of independent control mechanisms as well as lack of quantitative conclusive information on consumer needs and interests are retarding this evolution.

As a result, further research on the socio-technical construction and quality coordination of halal meat is recommended. One of the emerging socio-technical issues, both in public debates and on the political agenda, pertains to ritual slaughter. Furthermore, despite the growing importance of the halal market segment, little research has been conducted on Muslim consumers in general and many questions relating to their specific attitudes and food choices remain unaddressed. It is therefore also recommended that future research seek to illuminate Muslims' attitudes towards halal meat, their information seeking behavior, and their perceived need for and confidence in labeling initiatives. Finally, better insights in the influence of Islam on meat consumption in general and the role of acculturation in subcultures are needed in order to formulate recommendations for an efficient and more effective organization of the supply chain of halal meat.

\section{Notes}

1. The non-Muslims living in Muslim countries who are thus consuming halal foods explain the difference in total number of Muslims and the total number of halal consumers.

2. A young Muslim with North African migration parents is often called a "beur" in France.

3. For a comprehensive overview of these quality conventions, we refer to Sylvander (1995), Sauvée (1998), Marescotti (2000), and Vannoppen et al. (2004).

4. Differences between Islamic and Jewish dietary laws pertain mainly to what foods are permissible and the ritual slaughter method, more specifically the stunning, blessing, slaughter person, and inspection after slaughter. Jewish dietary laws and kosher consumerism are described by Grandin (1990), Eliasi and Dwyer (2002), Diamond (2000), Regenstein and Regenstein (1988), Regenstein et al. (2003a; 2003b), and Genack (1990).

5. Fatwa is a legal opinion concerning Islamic law.

6. In Islamic law there are five schools of thought: Hanafi, Shafi'i, Maliki, Hanbali, and Ja'feri.

\section{References}

Abdussalam, M. (1981). "Muslim attitudes to the slaughter of food animals." Animal Regulation Studies 3: 217-222.

Aldeeb Abu-Sahlieh, S. A. (2001). AVIS sur l'étourdissement des animaux avant leur abattage. Avis 01-162. Lausanne, Switzerland: Institut Suisse de droit comparé, ISDC.
Asp, E. H. (1999). "Factors influencing food decisions made by individual consumers." Food Policy 24: 287-294.

Bech-Larsen, T. and K. Grunert (2001). "Konsumentscheidungen bei Vertrauenseigenschaften: eine Untersuchung am Beispiel des Kaufes von ökologischen Lebensmitteln in Deutschland und Dänemark." Marketing-ZFP 23(3): 188197.

Becker, T., E. Benner, and K. Glitsch (2000). "Consumer perception of fresh meat quality in Germany." British Food Journal 102(3): 246-266.

Benkheira, M. H. (1995). "La nourriture carnée comme frontière rituelle. Les boucheries musulmanes en France." Archives de Sciences Sociales des Religions 92: 67-88.

Benkheira, M. H. (1997). "Alimentation, altérité et socialité. Remarques sur les tabous alimentaires coraniques." Archives Européennes de Sociologies 38(2): 237-287.

Benkheira, M. H. (1999). "Lier et séparer. Les fonctions rituelles de la viande dans le monde islamisé." L'Homme 152: 89-114.

Benkheira, M. H. (2002). "Le rite à la lettre. Régime carné et normes religieuses." In P. Bonte, A.-M. Brisebarre, and A. Gokalp (eds.), Sacrifices en islam. Espaces et temps d'un rituel, (pp. 63-93). Paris, France: CNRS Editions.

Bergeaud-Blackler, F. (2004). "Le chevillard et le sacrificateur: la viande halal entre logiques économiques, légales et religieuses." In S. Taussig and C. Fleury (eds.), L'islam en France, (pp. 537-545). Paris, France: Presses Universitaires de France.

Bergeaud-Blackler, F. (2005). "De viande halal à halal food: comment le halal s'est développé en France." Revu Européenne de Migrations Internationales 21(3): 125-147.

Bergeaud-Blackler, F. (2006). "Halal: d'une norme communautaire à une norme institutionnelle." Journal des Anthropologues: Des Normes à Boire et à Manger 106/107: 77103.

Blackwell, R. D., P. W. Miniard, and J. F. Engel (2001). Consumer Behavior. Orlando, Florida: Harcourt Inc.

Boltanski, L. and L. Thévenot (1991). De la justification. Les économies de la grandeur. Paris, France: Gallimard.

Bolton, D. J., A. M. Doherty, and J. J. Sheridan (2001). "Beef HACCP: Intervention and non-intervention systems." International Journal of Food Microbiology 66: 119-129.

Bonne, K. and W. Verbeke (2006). "Muslim consumer's attitude towards meat consumption in Belgium: Insights from a means-end chain approach." Anthropology of Food 5: 1-24.

Bousetta, H. and B. Maréchal (2004). L'islam et les musulmans en Belgique. Enjeux locaux \& cadres de réflexion globaux. Brussels, Belgium: Koning Boudewijnstichting.

Callon, M. (1991). "Réseaux technico-économiques et irréversibilité." In R. Boyer (ed.), Figures de l'irréversibilité, (pp. 195-230). Paris, France: l'Ecole des Hautes Etudes en Sciences Sociales.

Cenci-Goga, B. T., R. Ortenzi, E. Bartocci, A. Codega di Oliveira, and A. Vizzani (2004) "Ritual slaughter: Where the paradox lays." In J. De Tavernier and S. Aerts (eds.), Science, Ethics and Society. Preprints of the 5th Congress of the European Society for Agricultural and Food Ethics, September 2-4, 2004, (pp. 55-58). Leuven, Belgium: CABME, Centre for Agricultural Bio- and Environmental Ethics. 
Chaudry, M. M. (1992). "Islamic Food laws: Philosophical basis and practical implications." Food Technology 46: 92104.

Chaudry, M. M., M. A. Jackson, M. M. Hussaini, and M. N. Riaz (2000). Halal Industrial Production Standards. Chicago Illinois: J\&M Food Products Company.

Codex Alimentarius Commission (2003). Recommended International Code of Practice: General Principles of Food Hygiene, CAC/RCP 1-1969, Rev. 4-2003. Rome, Italy: Codex Alimentarius Commission.

Darby, M. and E. Karni (1973). "Free competition and the optimal amount of fraud." Journal of Law and Economics 16: $67-88$.

De Ley, H. (2004). Moslims in de Europese lekenstaten. Retrieved from http://www.flwi.uGhent.be/cie/RUG/deley30 1.htm\#1 on August 25, 2004.

De Roest, K. and M. Dufour (2000). "The interrelationship between PDO product specification, its link to the terroir and its technological development." In B. Sylvander, D. Barjolle, and F. Arfini (eds.), The Socio-economics of Origin Labelled Products in Agri-food Supply Chains: Spatial, Institutional and Coordination Aspects, (pp. 295-308). Paris, France: INRA Actes et Communications.

Delener, N. (1994). "Religious contrasts in consumer decision behaviour patterns: Their dimensions and marketing implications." European Journal of Marketing 28(5): 36-53.

Diamond, E. (2000). And I Will Dwell in Their Midst. Orthodox Jews in Suburbia. Chapel Hill, North Carolina: University of North Carolina Press.

Dindyal, S. (2003). "How personal factors, including culture and ethnicity, affect the choices and selection of food we make." Internet Journal of Third World Medicine 1(2): 27 33.

Eliasi, J. R. and J. T. Dwyer (2002). "Kosher and halal: Religious observances affecting dietary intakes." Journal of the American Dietetic Association 101(7): 911-913.

Eymard-Duvernay, F. (1989). "Conventions de qualité et formes de coordination." Revue Economique 40(2): 329-360.

Faragallah, M. H., W. R. Schumm, and F. J. Webb (1997). "Acculturation of Arab-American immigrants: An exploratory study." Journal of Comparative Family Studies 28(3): 182-203.

Fearne, A., S. Hornibrook, and S. Dedman (2001). "The management of perceived food risk in the food chain: A comparative study of retailer-led beef quality assurance schemes in Germany and Italy." International Food and Agribusiness Management Review 4: 19-36.

Foquz (1998). Vleesaankopen allochtonen. Utrecht, the Netherlands: Foquz.

Genack, M. (1990). "Industrial kashrut supervision." Judaism 39(4): 402-407.

Grandin, T. (1990). "Humanitarian aspects of shehitah in the U.S.” Judaism 39(4): 436-446.

Grunert, K. G. (2005). "Food quality and safety: Consumer perception and demand." European Review of Agricultural Economics 32: 369-391.

Haut Conseil à l'Intégration (2000). L'Islam dans la république. Paris, France: Haut Conseil à l'Intégration.

Hunter, B. T. (1997). "More consumers ask: Is it kosher?." Consumers' Research Magazine 80(4): 10-15.
Hussaini, M.M. (1993a). Halal Haram Lists. Why They Do Not Work? Retrieved from http://www.soundvision.com/info/halalhealthy/halal.list.asp on August 23, 2004.

Hussaini, M.M. (1993b). Islamic Dietary Concepts \& Practices. Bedford Park, Illinois: The Islamic Food \& Nutrition Council of America.

Islamic Food and Nutrition Council of America (2004). Muslim Demographics. Retrieved from http://www.ifanca.org/demographics.htm on August 23, 2004.

Jamal, A. (1996). "Acculturation: The symbolism of ethnic eating among contemporary British consumers." British Food Journal 98(10): 12-26.

Juska, A., L. Gouveia, J. Gabriel, and K. P. Stanley (2003). "Manufacturing bacteriological contamination outbreaks in industrialized meat production systems: The case of E. coli O157:H7." Agriculture and Human Values 20(1): 3-19.

Kirwan, J. (2006). "The interpersonal world of direct marketing: Examining conventions of quality at UK farmers' markets." Journal of Rural Studies 22: 301-312.

Kjaernes, U. and A. Dulsrud (1998). "Consumption and mechanisms of trust." Paper presented to the ESA subgroup, Sociology of Consumption, September 16-17, 1998, Milan, Italy.

Laroche, M., C. Kim, and M. A. Tomiuk (1999). "Italian ethnic identity and its relative impact on the consumption of convenience and traditional foods." British Food Journal 101(3): 201-228.

Levenstein, H. A. (1985). "The American response to Italian food 1880-1930." Food and Foodways 1(1): 1-24.

Lund, M. (2002). "The economics of HACCP: farm-to-table analysis.” In A. G. J. Velthuis, L. J. Unnevehr, H. Hogeveen and R. B. M. Huirne (eds.), New Approaches to Food-safety Economics. Proceedings of the Frontis Workshop on New Approaches to Food-safety Economics, April 14-17, 2002 (pp. 79-88). Wageningen, The Netherlands: Wageningen UR Frontis Series.

Maarabouni, A. (2002). Pour une gestion éthique des OGM. L'Islam et les OGM. Montréal, Canada: La Commission de l'Ethique de la Science et de la Technologie.

Marescotti, A. (2000). "Marketing channels, quality hallmarks and the theory of conventions." In B. Sylvander, B. Dominique, and A. Filippo (eds.), The Socio-economics of Origin Labeled Products in Agri-food Supply Chains: Spatial, Institutional and Coordination Aspects, (pp. 103122). Paris, France: INRA Editions.

Mennell, S., A. Murcott, and A. H. vanOotterloo (1992). The Sociology of Food: Eating, Diet and Culture. London, United Kingdom: Sage Publications Ltd.

Moses, V. (1999). "Biotechnology products and European consumers." Biotechnology Advances 17: 647-678.

Mullen, K., R. Williams, and K. Hunt (2000). "Irish descent, religion and food consumption in the west of Scotland." Appetite 34: 47-54.

Murdoch, J. (2000). "Networks - a new paradigm of rural development?." Journal of Rural Studies 16: 407-419.

Musaiger, A. O. (1993). "Socio-cultural and economic factors affecting food consumption patterns in the Arab countries." Journal of the Royal Society for the Promotion of Health 113(2): 68-74. 
Park, S., H.-Y. Paik, J. D. Skinner, S.-W. Ok, and A. A. Spindler (2003). "Mother's acculturation and eating behaviors of Korean American Families in California." Journal of Nutrition Education and Behavior 35(3): 142-147.

Pettinger, C., M. Holdsworth, and M. Gerber (2004). "Psychosocial influences on food choice in Southern France and Central England." Appetite 42: 307-313.

Regenstein, J. M. and C. E. Regenstein (1988). "The kosher dietary laws and their implementation in the food industry." Food Technology 42(6): 86-94.

Regenstein, J. M., M. M. Chaudry, and C. E. Regenstein (2003a). "The kosher and halal food laws." Comprehensive Reviews in Food Science and Food Safety 2(3): 111-127.

Regenstein, J. M., M. M. Chaudry, and C. E. Regenstein (2003b). "Kosher and halal in the biotechnology area." Applied Biotechnology, Food Science and Policy 34(2): 95-107.

Riaz, M. N. (1999). "Examining the halal market." Prepared Foods 168(10): 81-85.

Riaz, M. N. and M. M. Chaudry (2004). Halal Food Production. Boca Raton, Louisiana: CRC Press.

Sack, D. (2001). Whitebread Protestants, Food and Religion in American Culture. New York, New York: Palgrave.

Sakr, A. H. (1971). "Dietary regulations and food habits of Muslims." Journal of the American Dietetic Association 58: 123-126.

Salais, R. and M. Storper (1992). “The four 'worlds' of contemporary industry." Journal of Economics 16(2): 169-193.

Satia-Abouta, J., R. E. Patterson, M. L. Neuhouser, and J. Elder (2002). "Dietary acculturation: Applications to nutrition research and dietetics." Journal of the American Dietetic Association 102(8): 1105-1118.

Sauvée, L. (1998). "Toward an institutional analysis of vertical coordination in agribusiness." In J. S. Royer and R. C. Rogers (eds.), The Industrialization of Agriculture: Vertical Coordination in the US Food System, (pp. 27-71). Aldershot, UK: Ashgate Publishing.

Shatenstein, B., and P. Ghadirian (1998). "Influences on diet, health behaviours and their outcome in select ethnocultural and religious groups." Nutrition 14(2): 223-230.

Snijders, J. M. A. and F. vanKnapen (2002). "Prevention of human diseases by an integrated quality control system." Livestock Production Science 76: 2003-2006.

Steenkamp, J.-B. E. M. (1993). "Food consumption behaviour." European Advances in Consumer Research 1: 401-409.

Steptoe, A. and T. M. Pollard (1995). "Development of a measure of the motives underlying the selection of food: The food choice questionnaire." Appetite 25: 267-284.

Storper, M. (1997). "Les nouveaux dynamismes régionaux: conventions et systèmes d'acteurs." In S. Coté, J.-L. Klein, and M.-U. Proulx (eds.), Action collective et décentralisation, (pp. 1-17). Rimouski, Canada: GRIDEQ.
Straete, E.-P. (2004). "Innovation and changing "worlds of production': Case studies of Norwegian dairies." European Urban and Regional Studies 11(3): 227-241.

Sylvander, B. (1995). "Conventions de qualité, marches et institutions: le cas des produits spécifiques." In F. Nicolas and E. Valceschini (eds.), Agro-alimentaire: une économie de la qualité, (pp. 167-183). Paris, France: Economica.

Ten Eyck, T. A., D. Thede, G. Bode, and L. Bourquin (2006). "Is HACCP nothing? A disjoint constitution between inspectors, processors, and consumers and the cider industry in Michigan." Agriculture and Human Values 23(2): 205-214.

Vannoppen, J., G. Van Huylenbroeck, and W. Verbeke (2004). Economic Conventions and Consumer Valuation in Specific Food Supply Networks. Aachen, Germany: Shaker Verlag.

Verbeke, W. (2005). "Agriculture and the food industry in the information age." European Review of Agricultural Economics 32(3): 347-368.

Verbeke, W. and G. Poquiviqui Lopez (2005). "Ethnic food attitudes and behaviour among Belgians and Hispanics living in Belgium." British Food Journal 107(11): 823-840.

Wiskerke, J. S. C. (2003). "On promising niches and constraining socio-technical regimes: The case of Dutch wheat and bread." Environment and Planning 35: 429-448.

Wood, J. D., J. S. Holder, and D. C. J. Main (1998). "Quality assurance schemes." Meat Science 49(1): 191-203.

World Health Organization (1997). Report of a Seminar and Committees Organized by the Muslim World League and the World Health Organization. Retrieved from http:/www.emro.who.int/publications/helathEdRelgion/slaughter on September 9, 2004.

Wyss, G. S. and K. Brandt (2005). “Assessment of current procedures for animal food production chains and critical control points regarding their safety and quality: preliminary results from the Organic HACCP-project." In M. Hovi, M. Walkenhorst and S. Padel (eds.) Systems Development: Quality and Safety of Organic Livestock Products. Proceedings of the 4th SAFO Workshop, March 17-19, 2005 (pp 127-132). Frick, Switzerland: SAFO.

Zadernowski, M. R., W. Verbeke, R. Verhe, and A. Babuchowski (2001). "Toward meat traceability critical control point analysis in the Polish pork chain." Journal of International Food and Agribusiness Marketing 12(4): 5-22.

Address for correspondence: Wim Verbeke, Department of Agricultural Economics, Ghent University, Ghent, Belgium Phone: +32-(0)9-2646181; Fax: +32-(0)9-2646246;

E-mail: wim.verbeke@UGent.be 